\title{
Bacterial Metabolites Mirror Altered Gut Microbiota Composition in Patients with Parkinson's Disease
}

\author{
Sebastiaan P. van Kessel and Sahar El Aidy* \\ Department of Molecular Immunology and Microbiology, Groningen Biomolecular Sciences \\ and Biotechnology Institute (GBB), University of Groningen, Groningen, The Netherlands
}

Accepted 18 September 2019

\begin{abstract}
Increasing evidence is supporting the hypothesis of $\alpha$-synuclein pathology spreading from the gut to the brain although the exact etiology of Parkinson's disease (PD) is unknown. Furthermore, it has been proposed that inflammation, via the gastrointestinal tract, potentially through infections, may contribute to $\alpha$-synuclein pathogenesis, and thus to the risk of developing PD. Recently, many studies have shown that PD patients have an altered microbiota composition compared to healthy controls. Inflammation in the gut might drive microbiota alterations or vice versa. Many studies focused on the detection of biomarkers of the etiology, onset, or progression of PD however also report metabolites from bacterial origin. These metabolites might reflect the bacterial composition and as well play an important role in immune homeostasis, ultimately affecting the progression of PD. Besides the bacterial metabolites, pharmacological treatment of PD might play a crucial role during the progression and thus treatment of the disease on the immune system. This review aims to establish a link between the microbial composition with the observed alterations of bacterial metabolites and their impact on the immune system, which could have influential effect in onset, progression and etiology of PD.
\end{abstract}

Keywords: Microbiota composition, bacterial metabolites, immune modulators, Parkinson's disease, levodopa, dopamine

\section{INTRODUCTION}

Parkinson's disease (PD) is the second-most occurring neurodegenerative disorder worldwide [1]. The prevalence of PD increases with age and peaks at 1.5 $\%$ between 85 years and 89 years of age and 6.1-6.2 million individuals were diagnosed with PD globally in 2015-2016 [1, 2]. The main feature observed in PD patients is the aggregation of $\alpha$-synuclein in Lewy bodies and loss of dopaminergic neurons in

*Correspondence to: Sahar El Aidy, Department of Molecular Immunology and Microbiology, Groningen Biomolecular Sciences and Biotechnology Institute (GBB), University of Groningen, Nijenborgh 7, 9747 AG Groningen, The Netherlands. Tel.: +31 5036 32201; Fax: +31 5036 32154; E-mail: sahar. elaidy@rug.nl. the substantia nigra pars compacta [3]. It has been postulated that $\alpha$-synuclein pathology spreads out from the enteric nervous system of the gastrointestinal tract to the central nervous system in the brain [4]. Which is in agreement with the detection of $\alpha$-synuclein aggregates in colonic tissue and appendix prior to the onset of PD [5, 6]. Recently, it has been shown that pathogenic $\alpha$-synuclein aggregates spread from the gut to the brain in a mouse model, supporting Braak's hypothesis of the etiology of idiopathic PD [7]. Furthermore, increasing evidence supports the involvement of the peripheral immune system in PD. Inflammation via the gastrointestinal tract, potentially through infections, may contribute to disease pathogenesis, and to the risk of PD development, which was recently reviewed in 
$[8,9]$. Houser and Tansey proposed a model of PD pathogenesis originating from the gut where an initial inflammatory trigger could lead to a low-grade inflammation, driving shifts in the microbiota composition, and increasing gut permeability, thus allowing leakage of bacteria and their potential inflammatory metabolites [8]. This leakage in gut barrier would increase the blood-brain barrier permeability and $\alpha$ synuclein pathology, which would ultimately lead to neuroinflammation followed by neurodegeneration [8]. Indeed, PD patients have an altered microbiota composition compared to healthy controls (HC) [10-22], and one of the main bacterial metabolites, short chain fatty acids (SCFA), have been implicated in $\alpha$-synuclein pathology and microglia activation in a mouse model of PD [23]. Altered microbial composition could lead to a shift in circulating bacterial derived metabolites [24], and could be involved in low-grade inflammation, an important trigger for the onset of PD [8]. In this review, we aim to establish a link between the microbial composition and the reported alterations in their metabolic capacity that have profound immune modulating properties, which could potentially trigger onset, progression and etiology of PD.

\section{ALTERED BACTERIAL-DERIVED METABOLITES IN PATIENTS WITH PARKINSON'S DISEASE}

Although it is clear that PD patients have an altered microbiota composition [10-22], which was reviewed recently $[25,26]$ and updated and merged in Table 1 , there is a large variation among studies and there is no clear consensus about which bacteria might be involved, which might be due to several factors including sample storage, technical differences of sampling, sequencing methods, statistical approach, demographics, clinical details, and sample size [10]. Nevertheless, the altered microbiota composition could result in metabolic changes in PD patients which could play an important role in disease onset and progression of PD [24]. Therefore, many studies focused on metabolic biomarker screening (comparing healthy subjects with either familial PD or idiopathic PD), for an early detection of potential development of PD. The metabolic profiles of PD patients (in cerebrospinal fluid (CSF), blood or urine) usually reflect oxidative stress [24, 27-31] or mitochondrial dysfunction [24, 31-35]. However, many studies also observed differences in metabo- lites from bacterial origin, which are summarized in Table 2.

Comparing the 13 different studies in Table 1, 62\% (8/13) report a decrease in species from the Lachnospiraceae family (including Blautia sp., Dorea sp., Coprococcus sp., Rosburia sp., and Clostridium XIVa sp.), 38\% (5/13) report a decrease of Faecalibacterium sp., and 15\% (2/13) report a decrease in Bacteroides sp. (one study reported an increase), all of which are known to be SCFAs producers [36].

In mouse models, it was shown that the gut microbiota is involved in $\alpha$-synuclein aggregation pathology through their production of SCFAs [23]. Using murine models overexpressing $\alpha$-synuclein, germ-free (GF) or antibiotic treated mice had reduced $\mathrm{PD}$ pathology compared to conventional mice. In addition, when those GF or antibiotic treated mice were administered a mixture of SCFAs, the PD pathology was restored as observed in their conventional counterparts [23]. GF mice (WT or overexpressing $\alpha$-synuclein) colonized with human stool from PD patients had increased relative levels of butyrate and propionate but decreased levels of acetate compared to mice colonized with human stool from HCs [23]. These findings are in contrast with the finding that PD patients have decreased levels of absolute SCFAs and reduced relative levels of butyrate but not acetate and propionate in their stool samples compared to age matched HCs [14], which is in agreement with reduced levels of acetate found in the blood of PD patients [37]. This discrepancy is most likely because of the differences between humans and mice, specifically those born germ-free. In addition, in Sampson et al. (2016) [23] mice were recolonized with human faecal transplant, representing more acute effects as well as shifts in the microbiome based on species effects.

A decrease in Prevotellaceae or Prevotella sp. was observed in $31 \%(4 / 13)$ of the studies listed in Table 1. Prevotella produces (among others) hydrogen sulfide $\left(\mathrm{H}_{2} \mathrm{~S}\right)$, a gasotransmitter (for review see [38]), which has been linked to PD and neuroprotection [39]. Free $\mathrm{H}_{2} \mathrm{~S}$ levels in plasma, cecum, and colon of germ-free mice were significantly reduced compared to their conventional counterparts, indicating that the microbiota contributes to free $\mathrm{H}_{2} \mathrm{~S}$ levels [40]. $\mathrm{H}_{2} \mathrm{~S}$ breathing (40 ppm) restored the movement disorder, protected dopaminergic neurons, prevented microglia and astrocyte activation and upregulated the expression of antioxidant genes from the Nrf2 pathway in a 1-methyl-4phenyl-1,2,3,6-tetrahydropyridine (MPTP) induced 
Table 1

Bacterial composition alterations in PD patients compared to healthy controls

\begin{tabular}{|c|c|c|c|c|c|c|}
\hline Decreased & Increased & Method & PD & $\mathrm{HC}$ & Sample & Reference \\
\hline $\begin{array}{l}\text { Prevotellaceae*, Lachnospiraceae, } \\
\text { Puniceicoccaceae, Roseburia, Prevotella, } \\
\text { Blautia, Clostridium XIVa }\end{array}$ & $\begin{array}{l}\text { Bifidobacteriaceae*, Bifidobacterium*, } \\
\text { Rikenellaceae, Lactobacillaceae, } \\
\text { Lactobacillus }\end{array}$ & 16S rRNA & 64 & 64 & Feces & [10] \\
\hline Lachnospiraceae & $\begin{array}{l}\text { Akkermansia muciniphila, } \\
\quad \text { Enterobacteriaceae, Lactobacillaceae }\end{array}$ & 16S rRNA & 193 & 113 & Feces & [11] \\
\hline Prevotella copri, Eubacterium bioforme & $\begin{array}{l}\text { Akkermansia muciniphila, unclassified } \\
\text { Firmicutes }\end{array}$ & $\begin{array}{l}\text { Shotgun } \\
\text { metagenomics }\end{array}$ & 31 & 28 & Feces & [15] \\
\hline $\begin{array}{l}\text { Clostridium coccoides, Clostridium leptum, } \\
\text { Bacteroides fragilis, Prevotella (ns) }\end{array}$ & Lactobacillus sp. & $\begin{array}{l}\text { Targeted qPCR for } 19 \\
\text { species }\end{array}$ & 45 & 32 & Feces & [16] \\
\hline $\begin{array}{l}\text { Lachnospiraceae, Faecalibacterium } \\
\text { prausnitzii. }\end{array}$ & $\begin{array}{l}\text { Akkermansia muciniphila, Bifidobacterium } \\
\text { sp., Lactobacillus sp. }\end{array}$ & $16 \mathrm{~S}$ rRNA & 212 & 136 & Feces & [17] \\
\hline none & $\begin{array}{l}\text { Lactobacillaceae, Barnesiellaceae, } \\
\text { Enterococcaceae }\end{array}$ & 16S rRNA & 29 & 29 & Feces & [18] \\
\hline $\begin{array}{l}\text { Corpobacillaceae, Lachnospiraceae } \\
\text { (Blautia sp., Dorea sp., Roseburia sp., } \\
\text { Coprococcus sp.) }\end{array}$ & Bacteroides sp. & 16S rRNA & 38 & 34 & Feces & [19] \\
\hline $\begin{array}{l}\text { Coprobacillaceae, Lachnospiraceae (Dorea } \\
\text { sp.), Faecalibacterium sp. }\end{array}$ & Oxalobacteraceae, Ralstonia & 16S rRNA & 38 & 34 & Sigmoid mucosa & [19] \\
\hline $\begin{array}{l}\text { Blautia sp., Faecalibacterium sp., } \\
\text { Ruminococcus sp. }\end{array}$ & $\begin{array}{l}\text { Escherichia sp., Streptococcus sp., Proteus } \\
\text { sp., Enterococcus sp. }\end{array}$ & 16S rRNA & 24 & 14 & Feces & [20] \\
\hline Lachnospiraceae & Eubacteraceae, Bifidobacteraceae & 16S rRNA & 75 & 45 & Feces & [21] \\
\hline $\begin{array}{l}\text { Dorea sp., Bacteroides sp., Prevotella sp., } \\
\text { Faecalibacterium sp. }\end{array}$ & $\begin{array}{l}\text { Lactobacillus sp., Christensenella sp., } \\
\text { Catabacter sp., Oscillospira sp., } \\
\text { Bifidobacterium sp. }\end{array}$ & 16S rRNA & 89 & 66 & Feces & {$[22]$} \\
\hline $\begin{array}{l}\text { Prevotellaceae, Clostridales incertae sedis } \\
\text { IV }\end{array}$ & $\begin{array}{l}\text { Lactobacillaceae, Verrucomicrobiaceae } \\
\text { (Akkermansia), Bradyrhizobiaceae, } \\
\text { Ruminococcaceae, Enterobacteriaceae }\end{array}$ & 16S rRNA & 72 & 72 & Feces & [12] \\
\hline Lactobacillus, Sediminibacterium & $\begin{array}{l}\text { Clostridium IV, Aquabacterium, } \\
\text { Holdemania, Sphingomonas, Clostridium } \\
\text { XVIII, Butyricicoccus, Anaerotruncus }\end{array}$ & 16S rRNA & 45 & 45 & Feces & [13] \\
\hline $\begin{array}{l}\text { Bacteroidetes, Lactobacilli, } \\
\text { Faecalibacterium sp., Enterococcaceae, } \\
\text { Prevotellaceae (ns) }\end{array}$ & Enterobacteriaceae, Bifidobacterium sp. & $\begin{array}{l}\text { Targeted qPCR for } 9 \\
\text { taxa }\end{array}$ & 34 & 34 & Feces & [14] \\
\hline
\end{tabular}

actobacillus sp.

Lactobacillaceae, Barnesiellaceae,

coccaceae

Clautia sp., Dorea sp., Roseburia sp.,

. Falibacterium sp.

Faecalibacterium sp.,

Lachnospiraceae

orea sp., Bacteroides sp., Prevotella sp.,

Eubacteraceae, Bifidobacteraceae

acillus sp., Christensenella sp.,

Bifidobacterium sp.

coccaceae, Enterobacteriac

Holdemania, Sphingomonas, Clostridium

XVIII, Butyricicoccus, Anaerotruncus

Prevotellaceae (ns)

Updated table adapted and merged from [25] and [26]; *Also significant after the two-year follow up; ns, not significant. 
Table 2

Bacterial metabolites significantly altered in PD patients compared to healthy controls

\begin{tabular}{|c|c|c|c|c|c|c|c|}
\hline Study & Sample & PD & Healthy & Method & Decreased (FC, PD vs HC) & Increased (FC, PD vs HC) & Description \\
\hline [29] & CSF & 34 & 35 & GC-MS & none & none & Lumbar puncture after fasting. \\
\hline [31] & CSF & 31 & 95 & FT-ICR-MS & none & $p$-cresol sulfate (9.29); quinic acid (1.7) & $\begin{array}{l}\text { Lumbar puncture; } 18 \text { patients without PD } \\
\text { medications and } 11 \text { with PD medication. }\end{array}$ \\
\hline [90] & CSF & 48 & 57 & GC/LC-MS & none & none & $\begin{array}{l}\text { Postmortem (within } 4 \text { hours) collection of } \\
\text { lateral ventricular CSF. }\end{array}$ \\
\hline [91] & CSF & 10 & 10 & $1 \mathrm{D}{ }^{1} \mathrm{H}-\mathrm{NMR}$ & none & none & $\begin{array}{l}\text { Six patients started dopaminergic treatment } \\
\text { at the time of CSF collection. }\end{array}$ \\
\hline [55] & CSF, Plasma & 20 & 20 & GC-TOF-MS & none & none & $\begin{array}{l}\text { PD baseline; Samples were collected without } \\
\text { overnight fasting, between 8-9 AM. }\end{array}$ \\
\hline [48] & CSF, Plasma & $49^{*}$ & NA & LC-GC-MS & $\begin{array}{l}\text { Correlation with the progression of PD: } \\
\text { Benzoic acid (CSF: } r=-0.42 \text {, plasma: ns) }\end{array}$ & $\begin{array}{l}\text { Correlation with the progression of PD: } \\
\text { indoleacetic acid (CSF:0.29, plasma: ns) }\end{array}$ & $\begin{array}{l}\text { *Placebo treated PD patients from study } \\
\text { from 1989. Lumbar puncture for CSF } \\
\text { samples and blood samples were collected } \\
\text { after overnight bed rest (between } 6 \text { and } 10 \\
\text { AM before breakfast). }\end{array}$ \\
\hline [92] & CSF, Plasma & 22 & 28 & GC/LC-MS & 3-(4-hydroxyphenyl)acetic acid (NA) & indole (NA) & $\begin{array}{l}\text { Lumbar puncture and plasma samples from } \\
\text { non-fasting patients; Samples were age, } \\
\text { sex, and sampling-date matched. }\end{array}$ \\
\hline [93] & CSF, Plasma & 26 & 14 & LC-MS & none & none & $\begin{array}{l}\text { Lumbar punctures were performed between } \\
09.30 \text { and } 10.00 \text { am after overnight fasting; } \\
\text { Blood was drawn from the cubital fossa } \\
\text { immediately after the lumbar puncture. }\end{array}$ \\
\hline [37] & Plasma & 43 & 37 & $2 \mathrm{D}{ }^{1} \mathrm{H}-\mathrm{NMR}$ & $\begin{array}{l}\text { trimethylamine (NA), acetate (NA), } \\
\text { threonate (NA) }\end{array}$ & none & $\begin{array}{l}\text { Samples were obtained from drug-naïve PD } \\
\text { patients with age and gender-matched } \\
\text { healthy controls. }\end{array}$ \\
\hline [94] & Plasma & 53 & 46 & LC-ECA & none & none & $\begin{array}{l}\left.53 \text { PD patients ( } 41 \text { iPD, } 12 \text { LRRK2 } 2^{\mathrm{G} 2019 \mathrm{~S}}\right) \\
\text { were compared to } 31 \text { healthy family } \\
\text { members ( } 21 \text { positive and } 10 \text { negative for } \\
\text { LRRK } 2 \text { mutation) and } 15 \text { non-related } \\
\text { controls. }\end{array}$ \\
\hline [28] & Serum & 35 & 7 & GC/LC-MS & indoleacetic acid (0.67) & $\begin{array}{l}\text { phenyllactate (1.84); } \\
\text { 3-(4-hydroxyphenyl)lactate (1.23) }\end{array}$ & $\begin{array}{l}\text { Blood was withdrawn after } 4 \text { hours of } \\
\text { fasting. }\end{array}$ \\
\hline [33] & Serum & 41 & 40 & $\begin{array}{l}\text { DiscoveryHD } 4^{\mathrm{TM}} \\
\text { Metabolon } \\
\text { Platform }\end{array}$ & catechol sulfate $(0.62)$ & none & $\begin{array}{l}\text { Mass spectrometry-based; Blood was } \\
\text { withdrawn after fasting from } 41 \text { idiopathic } \\
\text { early-stage Parkinson's patients (disease } \\
\text { duration }<1 \text { year). }\end{array}$ \\
\hline
\end{tabular}



[32] Serum
18
[24] Serum
(1)

\section{LC-MS}
LC-MS

$[68]$

$48^{\#}$

10

LC-MS

20
LC-FT-ICR-MS

none

none

acetate $\left(0.43^{\mathrm{f}}, 0.71^{\mathrm{g}}\right)$, butyrate $\left(0.38^{\mathrm{f}}\right.$, $\left.0.57^{\mathrm{g}}\right)$, propionate $\left(0.48^{\mathrm{f}}, 0.61^{\mathrm{g}}\right)$

phenylethylamine $\left(0.34^{\mathrm{d}}, 0.16^{\mathrm{e}}\right)$

\section{none}

none

doleacetic acid (0.82); hippuric acid

(0.52); 3-hydroxyhippuric acid (0.39);

catechol sulfate $(0.62)$;

3-(3-hydroxyphenyl)propionic acid (0.49);

indole-3-methyl acetate (0.70);

2-Furoylglycine $(0.37)$

tyramine $\left(1.70^{\mathrm{d}}, 2.44^{\mathrm{e}}\right)$

none

3-(4-hydroxyphenyl)acetic acid (1.96-2.16); tryptamine (2.22-3.31); indoleacetic acid

(1.66-3.23); phenylacetic acid (2.36-2.71)

3-(4-hydroxyphenyl)acetic acid (1.66 ${ }^{\mathrm{a}}$,

$\left.2.78^{\mathrm{b}}, 5.85^{\mathrm{c}}\right)$; indoleacetic acid $\left(2.64^{\mathrm{a}}\right.$,

$\left.3.49^{\mathrm{b}}, 1.88^{\mathrm{c}}\right)$; aminobenzoic acid $\left(6.63^{\mathrm{a}}\right.$,

$\left.25.43^{\mathrm{b}}, 16.74^{\mathrm{c}}\right)$; hydroxybenzoic acid

$\left(4.30^{\mathrm{a}}, 4.26^{\mathrm{b}}, 6.68^{\mathrm{c}}\right)$

none
Determined of PD patients not developing dementia $(n=27)$ and PD patients that did develop dementia $(n=16)$. Blood was

withdrawn at baseline.

Blood was withdrawn in the morning before any food or drink.

PARK2 PD patients; Blood was withdrawn after overnight fasting.

\#21 de novo PD patients, ${ }^{\mathrm{d}}$ de novo $\mathrm{PD}$ patients, ${ }^{\mathrm{e}}$ treated PD patients; Blood was withdrawn in the morning after fasting.

39 rapid progressing PD Patients and 41

slowly progressing PD patients. No fasting was required. No medication was allowed in the morning. Samples were taken at the morning exam between $8 \mathrm{AM}$ and $12 \mathrm{PM}$

After overnight fasting morning midstream urine samples were collected at week 0,16 and 32 .

After overnight fasting morning midstream urine samples were collected at week 0,16 and 32; ${ }^{\text {EE}}$ Early-stage (HY 1-1.5),

${ }^{\mathrm{b}}$ Mid-stage (HY 2-2.5), ${ }^{\mathrm{c}}$ Advanced-stage (HY 3-4).

$\$ 34$ age matched controls and 10 young healthy controls. Fold changes derived from figure compared to young controls ${ }^{\mathrm{g}}$ and age matched controls ${ }^{\mathrm{f}}$. All subjects were on an omnivorous diet without special dietary habits or restrictions. During the last 3 months no intake of antibiotics, probiotics, or prebiotics was reported.

*Parkinson Study Group. Effect of deprenyl on the progression of disability in early Parkinson's disease. N Engl J Med 1989;321:1364-1371. GC, gas chromatography; LC, liquid chromatography, MS, mass spectrometry; CIT, chemical isotope labeling; FT-ICR, Fourier-transform ion cyclotron resonance; NMR, nuclear magnetic resonance; LC-ECA, LC, electrochemical Array. 
PD mouse model [41]. Similar results were found in a 6-hydroxydopamine (6-OHDA) and rotenone induced PD rat model receiving 30 or $100 \mu \mathrm{mol} / \mathrm{kg}$ NaHS (an $\mathrm{H}_{2} \mathrm{~S}$ donor) [42]. Similarly, $\mathrm{H}_{2}$ another and potentially overlooked gasotransmitter, which can be produced by gut microbiota, such as Blautia sp. Clostridium spp., might have an important link to PD as it has been described to neutralize toxic hydroxyl radicals, downregulate the expression of proinflammatory factors, and preserve cerebrovascular reactivity [43]. Intriguingly, $0.08 \mathrm{ppm}$ of $\mathrm{H}_{2}$ in drinking water reduced the loss dopaminergic neurons by $16 \%$ compared to the control in the substantia nigra and slightly improved the mobility in an open-field test using a MPTP induced PD mouse model [44]. Similarly, the protection of dopaminergic neurons, by drinking hydrogenated water, was also observed in a 6-OHDA rat model [45]. Bacterial species representing the genera of bacteria altered in $\mathrm{PD}$ have been tested for their production of $\mathrm{H}_{2}$ [46]. Blautia coccoides and Clostridium leptum, which are reported to be underrepresented in PD patients (Table 1) produced the highest levels of $\mathrm{H}_{2}(\sim 1.6$ and $0.62 \mu \mathrm{mol} / 10^{8}$ cells) [46], and therefore might contribute to the availability of molecular $\mathrm{H}_{2}$ which potentially plays a role in neuroprotection.

Other organic metabolites produced by Clostridium species [47] were found to be differentially present in serum, urine, and CSF samples of PD patients (Table 2). For example, an increase in 3phenyllactate, and 3-(4-hydroxyphenyl)lactic acid and a decrease of indoleacetic acid (IAA) was observed in serum of patients with idiopathic PD and familial PD (PARK2 mutations) [24, 28], although in urine, an increase of 3-(4-hydroxyphenyl)acetic acid and IAA was observed [34, 35]. In addition, a minor but significant correlation was observed between IAA and the progression of PD in CSF but not in plasma, however these samples were stored for 25 years before analysis on LC/GC-MS, which could influence the accuracy of sample analysis [48]. IAA is produced via oxidative decarboxylation or deamination of indolepyruvate or tryptamine, respectively. Levels of IAA and tryptamine, produced by Ruminococcus gnavus and Clostridium sporogenes [49], are strongly dependent on the microbiota as GF mice showed $\sim 30$ fold decrease in IAA cecal or fecal levels and a corresponding $\sim 10$ fold decrease in tryptamine levels when compared to their conventional raised counterparts $[50,51]$. Congruously to the increased IAA levels in urine, an increase in tryptamine was detected in urine of PD patients in one of the studies [35]. Importantly, IAA was shown to modulate inflammatory responses reducing pro-inflammatory cytokine production by macrophages stimulated with LPS and palmitate or attenuating the cytokine mediated lipogenesis through the aryl hydrogen receptor (AHR) in hepatocytes [51]. Furthermore, IAA has an antineuroinflammatory activity in LPS-stimulated BV2 microglial cells [52]. Taken together, data available suggest that altered levels of IAA, which are caused by changes in microbial composition, might play a role in attenuating inflammation in PD patients.

$p$-Cresol sulfate (sulfonated by the liver), which is exclusively produced by gut bacteria [53], mainly by species belonging to Clostridiaceae (Clostridium clusters I, IV, IX, XI, XIII, XIVa, XVI) and Bacteroidaceae families [54] (Table 1), is also observed to be $\sim 10$ fold increased in in the CSF of PD patients [31] but not in blood samples [24, 28]. However, differential metabolite levels in blood do not necessarily reflect CSF levels [55]. $p$-Cresol has a profound effect on the inflammatory response of macrophages and T-cells [56-58]. In murine peritoneal exudate cells (the adherent fraction, mainly macrophages) and in a J774.1 macrophage cell line, pre-treatment with $p$ cresol at non-cytotoxic levels was able to inhibit Il-12 production after stimulation with heat-killed Lactobacillis casei [56]. The same effect was observed later in murine peritoneal exudate cells and RAW276.3 macrophage cell-line stimulated with LPS or LPS and IFN $\gamma$ [58]. In addition, $p$-cresol sulfate increased Il-10 levels but did not alter levels of TNFa [58]. In a hypersensitive mouse model, $p$-cresol and $p$ cresol sulfate correlated negatively with ear swelling, suggesting that $p$-cresol (sulfate) attenuates $\mathrm{T}$ cell mediated immune response [57]. When in vitro $\mathrm{CD}^{+}$ splenocytes were stimulated with $p$-cresol or $p$-cresol sulfate a decrease in IFN $\gamma$ and an increase IL-4 levels were observed, which was confirmed by a decreased $\mathrm{Th} 1 / \mathrm{Th} 2$ ratio $\left(\mathrm{CD}^{+} / \mathrm{CD}^{+}\right.$splenocytes, intracellular stained for IFN $\gamma$ (Th1) or IL-4 (Th2) production), but no difference between untreated and $p$-cresol treated cytotoxic T-cells or regulatory T-cells were found [57].

In contrast to $p$-cresol sulfate, catechol sulfate, a product of bacterial and human co-metabolism, was found to be decreased in PD patients [24, 33]. Catechol is an intermediate bacterial product from the benzoate degradation pathway $[59,60]$. Notably, higher bacterial metabolism of catechol seems to be associated with inflammation as concluded from the higher relative abundance of bacteria representing 
the benzoate pathway are higher in a murine colitis model during the active disease compared to remission [60]. For example, Ralstonia pickettii, which is known to produce and degrade catechol $[61,62]$ was reported to be increased in the sigmoid mucosa of PD patients (Table 1) potentially reflecting inflammation [19], which is in agreement with the reported higher abundance of bacteria representing the benzoate degradation pathway [60].

Molecular mimicry by extracellular amyloid proteins produced by bacteria have been proposed as one potential trigger inducing misfolding of neuronal proteins via cross-seeding [63]. Recently the amyloid protein produced by Escherichia coli (curli) has been implicated in $\alpha$-synuclein pathology in rats and Caenorhabditis elegans [64]. Rats orally administered with wild type $E$. coli or $E$. coli lacking the curli-gene revealed increased $\alpha$-synuclein aggregates in the brain and gut of rats (hippocampus, striatum, and enteric nervous system) when treated with wild type E. coli. Furthermore, increased expression of IL-6, TLR2 and TNF were observed in the striatum or rats treated with wild type E. coli [64]. Various species from the Enterobacteriaceae family (E. coli, Salmonella typhimurium Citrobacter sp., Citrobacter freundii, Cronobacter sakazakii, and Proteus mirabilis) produce curli [65]. Importantly, 31\% (4/13) of the studies reported increased abundance of Enterobacteriaceae spp. [11, 12, 14, 20] (Table 1). Intriguingly, oral administration of $P$. mirabilis in a MPTP induced PD mouse model induced neuronal damage, motor deficits, neuroinflammation and $\alpha$-synuclein aggregation [66]. The authors suggested that higher levels of LPS by $P$. mirabilis induced the observed neuronal damage. However, the fact that P. mirabilis produces curli could be another factor involved in the observed PD pathology.

\section{BACTERIAL-MEDIATED SIDE EFFECTS OF PARKINSON'S DISEASE TREATMENT}

Orally administered PD medication could have an effect on gastrointestinal (GI) function and therefore on the microbial composition alterations in PD patients. For example, the COMT-inhibitors, anticholinergics and levodopa/carbidiopa (borderline significant) were associated with microbiota alterations within PD patients [17]. Furthermore, COMT-inhibitors were significantly associated with an increase of Lactobacillaceae and a decrease of
Clostridiales Family IV (Incertae Sedis) [12]. In 54\% (7/13) of the studies Lactobacillaceae or Lactobacillus were reported to be increased in PD patients (Table 1). Some Lactobacillus species are known to produce tyramine [67] and tyramine has been proposed as a biomarker for PD patients because of the significantly higher levels of tyramine compared to HC observed in the blood circulation (2.4 and 1.7 fold, respectively) [68], Table 2. Although other studies did not find an increase in tyramine, an increase in the downstream metabolite of tyramine, 3-(4-hydroxyphenyl) acetic acid, was observed in PD patients $[34,35]$, potentially supporting increased levels of tyramine. The authors associated the human aromatic amino acid decarboxylase (AADC, also known as DOPA decarboxylase (DDC)) with the observed levels, without speculating about possible contribution of gut bacteria. Tyramine is abundant in fermented foods particularly produced by lactic acid bacteria (Lactobacillus sp., Enterococcus sp.) harboring tyrosine decarboxylases (TDC), which are also commensals in the human GI-tract $[67,69,70]$. Tyramine is produced in the small intestinal content of rat, indicating that small intestinal bacteria contribute to tyramine levels in vivo. In addition, $t d c$-gene abundance correlated positively $(r=0.82, n=10)$ with the disease duration of PD [71], supporting the increased abundance of Lactobacillaceae or Lactobacillus found in PD patients. Besides the decarboxylation of tyrosine to tyramine, the study also showed that bacteria harboring TDC can effectively decarboxylate levodopa to dopamine, and might compromise the levels of levodopa in the gut, before it can reach the brain [71], which was later independently confirmed in human stool samples and using a TDC inhibitor in mice colonized with E. faecalis [72]. Co-prescribed decarboxylase inhibiters, mainly carbidopa, prevent peripheral decarboxylation of levodopa treatment by the human AADC (DDC), which however do not affect the bacterial TDCs [71]. The inadequate blocking of bacterial TDC might result in higher levels of luminal dopamine produced by the gut bacteria (65). Thus, because of levodopa treatment, PD patients are exposed to higher circulating levels of dopamine compared to matched HCs. Indeed, serum dopamine levels (sulfonated by the liver) are found to be 30-40 times higher compared to HC [24] and serum dopamine levels correlated with the dosage of levodopa [73]. Comparing healthy and PD subjects on either a low dose $(400 \mathrm{mg} /$ day $)$ or a on a high dose $(700 \mathrm{mg} /$ day) of levodopa showed that PD patients on a high dosage of levodopa have 
significantly more dopamine in their peripheral blood lymphocytes (PBLs), however, (nor)epinephrine or DOPAC levels were not altered [74]. In contrast, nontreated PD patients have low dopamine levels in their PBLs, even $\sim 3$ fold lower than in healthy subjects, but after treatment showed an $\sim 30$ fold increase in the PBL dopamine content [75]. Likewise, higher levels of dopamine were detected in plasma of levodopa treated PD patients ( $\sim 2.5$ fold increase) compared to $\mathrm{HC}$ or de novo PD patients and no significant differences were observed between $\mathrm{HC}$ and de novo $\mathrm{PD}$ patients [76].

The high levels of dopamine exposure in PD patients, resulting from bacterial and human levodopa metabolism, could affect immune homeostasis, as dopaminergic systems are involved in either the adaptive and innate immune system, recently reviewed $[77,78]$. Dopamine receptors are widely expressed on human leukocytes and dopamine, through its receptors, can modulate T-cell response, and might act as auto- or paracrine signaling molecule in the cells of the immune system [78]. Importantly, the percentage of Dopamine Receptor D5 (DRD5) positive CD4 ${ }^{+}$T-cells correlated negatively with the UPDRSIII (Unified Parkinson's Disease Rating Scale, Part III, motor examination) score [76], indicating that the severity (progression) of the disease, and thus the disease duration [79] and drug treatment might be associated with reduced $\mathrm{DRD5}{ }^{+} \mathrm{CD} 4^{+}$T-cells. A follow up study investigating $\mathrm{CD} 4^{+} \mathrm{T}$ cell subsets ( $\mathrm{T}$ helper cells, $\mathrm{T}_{\mathrm{H} 1}, \mathrm{~T}_{\mathrm{H} 2}, \mathrm{~T}_{\mathrm{H} 17}$; and $\mathrm{T}$ regulatory cells, $\mathrm{T}_{\text {reg }}$ ) showed an overall decrease of $\mathrm{CD} 4^{+} \mathrm{T}$ cells in de novo PD patients and treated PD patients attributed by a decrease in most T-cell subsets except for $\mathrm{T}_{\mathrm{H} 1}$. Remarkably, there were little differences observed between the de novo PD and treated PD patients except for $\mathrm{T}_{\text {reg }}$ mediated inhibition of $\mathrm{T}$ effector cell ( $\mathrm{T}_{\text {eff }}$, mixture of $\mathrm{T}$ helper cells) proliferation by dopamine. $\mathrm{T}_{\text {reg }}$ subsets from healthy subjects, de novo $\mathrm{PD}$ patients, and treated PD patients showed similar $\mathrm{T}_{\text {reg }}$ mediated inhibition of $\mathrm{T}_{\text {eff }}$ proliferation, which is almost abolished by dopamine except for $\mathrm{T}_{\text {reg }}$ cells isolated from treated PD patients, those cells appeared to be insensitive to dopamine [80]. This finding is consistent with an earlier report showing that dopamine prevents inhibition of murine $\mathrm{T}_{\text {eff }}$ proliferation by $\mathrm{T}_{\text {reg }}$ cells [81]. Furthermore, it was shown that the effect of dopamine was mediated through DRD1-like receptors (DRD1 or DRD5) [81], which is in agreement with the negative correlation observed between disease severity (and thus indirectly disease and treatment duration) and $\mathrm{DRD}^{+}$
$\mathrm{CD}^{+}$T-cells in PD patients [76]. This $\mathrm{T}_{\text {reg }}$ insensitivity might potentially be originated from the long-term levodopa treatment of PD patients. In addition, DRD2-like receptors (D2, D3, D4) seem to be involved in the dopaminergic immune pathway in PD. DRD3 knock out (KO) mice or RAG1 KO mice (which are devoid of $\mathrm{T}$ and $\mathrm{B}$ cells) reconstituted with DRD3-deficient splenocytes or DRD3-deficient $\mathrm{CD}^{+}{ }^{+} \mathrm{T}$ cells resulted in a strong neuroprotection in MPTP-induced PD, showing a fundamental role of DRD3 expressed on $\mathrm{CD}^{+}{ }^{+} \mathrm{T}$ cells in the degeneration of dopaminergic neurons. Furthermore it was shown that DRD3 deficient CD4 ${ }^{+} \mathrm{T}$ cells are unable to acquire the $\mathrm{T}_{\mathrm{h} 1}$ effector phenotype, indicating that dopaminergic signaling (by dopamine or agonists) through DRD3 would produce $\mathrm{T}_{\mathrm{h} 1}$ cells which are key in neurodegeneration observed [82]. Which is in agreement with the higher Th1/Th2 ratio observed in progressing $\mathrm{PD}$ patients but not in de novo $\mathrm{PD}$ patients, potentially through dopamine mediated $\mathrm{T}_{\mathrm{h}}$ differentiation in combination with the inability of $\mathrm{T}_{\text {reg }}$ cells to inhibit $\mathrm{T}_{\text {eff }}$ cells [80].

Besides levodopa, which results in higher exposer to peripheral dopamine, blocking DDC to avoid peripheral conversion of levodopa to dopamine, might have a profound influence on the immune system. Recently, it has been reported that carbidopa, a DDC inhibitor, has immunosuppressive properties as it prevents T-cell proliferation and T-cell autoimmunity in a mouse model [83]. Furthermore, it has been demonstrated that carbidopa is an AHR-ligand [84], and therefore might play a role in the immune system, as AHR is an important contributor to the adaptive immune system by modulating T-cell differentiation, reviewed recently [85].

Importantly, proliferation of murine B-cell enriched lymphocyte cultures isolated from spleen, lymph nodes and Peyer's patches are inhibited by dopamine in a concentration dependent manner $(1-100 \mu \mathrm{M})$, which coincided with immunoglobulin production $(\operatorname{Ig} \mathrm{A}, \operatorname{IgM}, \operatorname{IgG})$ [86]. $\operatorname{Ig} \mathrm{A}$ is known to shape the microbiota composition, reviewed here [87], and thus a decrease in IgA production due to the exposure to dopamine could potentially lead to alteration in the microbiota composition. In a recent study, inflammatory markers in fecal samples of PD patients were compared to their HCs counterparts. The mean levels of the angiogenesis factor (Flt1), the pro-inflammatory cytokines IL- $1 \alpha$, and CXCL8 were significantly higher in PD patients. Importantly, consumption of probiotics was associated with significantly higher levels of the chemokines 
CCL4 (MIP-1 $\beta$ ), and CCL17 (TARC), and the pro-inflammatory cytokine IL-7 [88]. Unfortunately, the potential effect of anti-Parkinson medication on the fecal immune profiles was not included in the analysis, which could have a profound effect on the outcome (discussed above).

\section{CONCLUSION}

Microbial dysbiosis might be a contributing factor to the onset and/or progression and severity of PD. Altered bacterial composition might result in a change in bacterial metabolites as detected in PD patients, contributing to the immune homeostasis, and potentially detrimental for the onset and progression of the disease. Equally important is the pharmacological treatment of $\mathrm{PD}$, which might further contribute to a disturbed immune system. Nonetheless, it remains to be elucidated what drives the modulation of the microbial composition in PD patients. Many studies have focused on the metabolic profile of PD patients in CSF, blood, or urine in order to find potential biomarkers for the etiology, onset, or progression of the disease. Many of these altered metabolites are bacterial products, reflecting a deviation in the microbial composition of PD patients, and therefore might act as an important biomarker for microbial dysbiosis. In addition, those bacterial-derived metabolites show important immunomodulatory properties, which might be important for the progression of the disease.

The main metabolites found have phenol/indole moieties and are mainly produced by bacteria from the Clostrida class, which are also known SCFAs producers. Notably, alterations in SCFAs were not reported in the majority of metabolomics studies, most likely because of the methods used for the untargeted metabolomics. Because SCFAs have a potential effect on the $\alpha$-synuclein pathology, targeted metabolomics for SCFAs should be performed in future metabolomics studies, as they might give clues about abnormal levels in PD patients potentially influencing PD pathology. Furthermore, altered levels of SCFAs could be linked with the levels of $p$-cresol and IAA as these metabolites are produced mainly by Clostridia $[47,54]$, the main butyrate producing bacteria in the gut [89]. Taken together, further research on the metabolites produced by the gut microbiota is necessary to unravel the complex interaction of multiple facets of metabolites originating from altered microbial composition and pharma- cological treatment on the immune system in PD patients to give further insights on the role of gut microbiota and their metabolites on the onset, progression and etiology of the disease. Standardized methods of stool sampling and sequencing technology should be developed to generate more consensus among metabolomic and microbiota studies. Additionally studies should be conducted with focus on determining the fecal metabolome from PD patients in context of the pathology and progression of the disease. Diet as well as medication are confounding factors that influence changes in the microbiota, thus should be taken into consideration in the data analyses.

\section{ACKNOWLEDGMENTS}

Rosalind Franklin Fellowships, co-funded by the European Union and University of Groningen, funded this research. Funding was acquired by S.E.A.

\section{CONFLICT OF INTEREST}

The authors have no conflict of interest to report.

\section{REFERENCES}

[1] GBD 2015 Neurological Disorders Collaborator Group (2017) Global, regional, and national burden of neurological disorders during 1990-2015: A systematic analysis for the Global Burden of Disease Study 2015. Lancet Neurol 16, 877-897.

[2] GBD 2016 Parkinson's Disease Collaborators (2018) Global, regional, and national burden of Parkinson's disease, 1990-2016: A systematic analysis for the Global Burden of Disease Study 2016. Lancet Neurol 17, 939-953.

[3] Braak H, Tredici K Del, Rüb U, de Vos RA, Jansen Steur EN, Braak E (2003) Staging of brain pathology related to sporadic Parkinson's disease. Neurobiol Aging 24, 197-211.

[4] Braak H, Rüb U, Gai WP, Del Tredici K (2003) Idiopathic Parkinson's disease: Possible routes by which vulnerable neuronal types may be subject to neuroinvasion by an unknown pathogen. J Neural Transm 110, 517-536.

[5] Killinger BA, Madaj Z, Sikora JW, Rey N, Haas AJ, Vepa $\mathrm{Y}$, Lindqvist D, Chen H, Thomas PM, Brundin P, Brundin L, Labrie V (2018) The vermiform appendix impacts the risk of developing Parkinson's disease. Sci Transl Med 10, eaar5280.

[6] Shannon KM, Keshavarzian A, Dodiya HB, Jakate S, Kordower JH (2012) Is alpha-synuclein in the colon a biomarker for premotor Parkinson's Disease? Evidence from 3 cases. Mov Disord 27, 716-719.

[7] Kim S, Kwon S-H, Kam T-I, Panicker N, Karuppagounder SS, Lee S, Lee JH, Kim WR, Kook M, Foss CA, Shen C, Lee H, Kulkarni S, Pasricha PJ, Lee G, Pomper MG, Dawson VL, Dawson TM, Ko HS (2019) Transneuronal propagation of pathologic $\alpha$-synuclein from the gut to the brain models Parkinson's disease. Neuron 103, 627-641.e7. 
[8] Houser MC, Tansey MG (2017) The gut-brain axis: Is intestinal inflammation a silent driver of Parkinson's disease pathogenesis? NPJ Parkinsons Dis 3, 3 .

[9] Tansey MG, Romero-Ramos M (2019) Immune system responses in Parkinson's disease: Early and dynamic. Eur J Neurosci 49, 364-383.

[10] Aho VTE, Pereira PAB, Voutilainen S, Paulin L, Pekkonen E, Auvinen P, Scheperjans F (2019) Gut microbiota in Parkinson's disease: Temporal stability and relations to disease progression. EBioMedicine 44, 691-707.

[11] Barichella M, Severgnini M, Cilia R, Cassani E, Bolliri C, Caronni S, Ferri V, Cancello R, Ceccarani C, Faierman S, Pinelli G, De Bellis G, Zecca L, Cereda E, Consolandi C, Pezzoli G (2019) Unraveling gut microbiota in Parkinson's disease and atypical parkinsonism. Mov Disord 34, 396-405.

[12] Scheperjans F, Aho V, Pereira PAB, Koskinen K, Paulin L, Pekkonen E, Haapaniemi E, Kaakkola S, Eerola-Rautio J, Pohja M, Kinnunen E, Murros K, Auvinen P (2015) Gut microbiota are related to Parkinson's disease and clinical phenotype. Mov Disord 30, 350-358.

[13] Qian Y, Yang X, Xu S, Wu C, Song Y, Qin N, Chen S, Xiao Q (2018) Alteration of the fecal microbiota in Chinese patients with Parkinson's disease. Brain Behav Immun 70, 194-202.

[14] Unger MM, Spiegel J, Dillmann K, Grundmann D, Philippeit H, Bürmann J, Faßbender K, Schwiertz A, Schäfer K-H (2016) Short chain fatty acids and gut microbiota differ between patients with Parkinson's disease and age-matched controls. Parkinsonism Relat Disord 32, 6672 .

[15] Bedarf JR, Hildebrand F, Coelho LP, Sunagawa S, Bahram M, Goeser F, Bork P, Wüllner U (2017) Functional implications of microbial and viral gut metagenome changes in early stage L-DOPA-naive Parkinson's disease patients. Genome Med 9, 1-13.

[16] Hasegawa S, Goto S, Tsuji H, Okuno T, Asahara T, Nomoto K, Shibata A, Fujisawa Y, Minato T, Okamoto A, Ohno K, Hirayama M (2015) Intestinal dysbiosis and lowered serum lipopolysaccharide-binding protein in Parkinson's disease. PLoS One 10, 1-15.

[17] Hill-Burns EM, Debelius JW, Morton JT, Wissemann WT, Lewis MR, Wallen ZD, Peddada SD, Factor SA, Molho E, Zabetian CP, Knight R, Payami H (2017) Parkinson's disease and Parkinson's disease medications have distinct signatures of the gut microbiome. Mov Disord 32, 739-749.

[18] Hopfner F, Künstner A, Müller SH, Künzel S, Zeuner KE, Margraf NG, Deuschl G, Baines JF, Kuhlenbäumer G (2017) Gut microbiota in Parkinson disease in a northern German cohort. Brain Res 1667, 41-45.

[19] Keshavarzian A, Green SJ, Engen PA, Voigt RM, Naqib A, Forsyth CB, Mutlu E, Shannon KM (2015) Colonic bacterial composition in Parkinson's disease. Mov Disord 30, 13511360 .

[20] Li W, Wu X, Hu X, Wang T, Liang S, Duan Y, Jin F, Qin B (2017) Structural changes of gut microbiota in Parkinson's disease and its correlation with clinical features. Sci China Life Sci 60, 1223-1233.

[21] Lin A, Zheng W, He Y, Tang W, Wei X, He R, Huang W, Su Y, Huang Y, Zhou H, Xie H (2018) Gut microbiota in patients with Parkinson's disease in southern China. Parkinsonism Relat Disord 53, 82-88.

[22] Petrov VA, Saltykova IV, Zhukova IA, Alifirova VM, Zhukova NG, Dorofeeva YB, Tyakht AV, Kovarsky BA, Alekseev DG, Kostryukova ES, Mironova YS, Izhboldina OP, Nikitina MA, Perevozchikova TV, Fait EA, Babenko
VV, Vakhitova MT, Govorun VM, Sazonov AE (2017) Analysis of gut microbiota in patients with parkinson's disease. Bull Exp Biol Med 162, 734-737.

[23] Sampson TR, Debelius JW, Thron T, Janssen S, Shastri GG, Ilhan ZE, Challis C, Schretter CE, Rocha S, Gradinaru V, Chesselet M, Keshavarzian A, Shannon KM, KrajmalnikBrown R, Wittung-Stafshede P, Knight R, Mazmanian SK (2016) Gut microbiota regulate motor deficits and neuroinflammation in a model of Parkinson's disease. Cell 167, 1469-1480.e12.

[24] Okuzumi A, Hatano T, Ueno SI, Ogawa T, Saiki S, Mori A, Koinuma T, Oji Y, Ishikawa KI, Fujimaki M, Sato S, Ramamoorthy S, Mohney RP, Hattori N (2019) Metabolomics-based identification of metabolic alterations in PARK2. Ann Clin Transl Neurol 6, 525-536.

[25] Sampson T (2019) The impact of indigenous microbes on Parkinson's disease. Neurobiol Dis, 104426.

[26] Sun MF, Shen YQ (2018) Dysbiosis of gut microbiota and microbial metabolites in Parkinson's disease. Ageing Res $\operatorname{Rev}$ 45, 53-61.

[27] de Farias CC, Maes M, Bonifácio KL, Bortolasci CC, de Souza Nogueira A, Brinholi FF, Matsumoto AK, do Nascimento MA, de Melo LB, Nixdorf SL, Lavado EL, Moreira EG, Barbosa DS (2016) Highly specific changes in antioxidant levels and lipid peroxidation in Parkinson's disease and its progression: Disease and staging biomarkers and new drug targets. Neurosci Lett 617, 66-71.

[28] Hatano T, Saiki S, Okuzumi A, Mohney RP, Hattori N (2016) Identification of novel biomarkers for Parkinson's disease by Metabolomic technologies. J Neurol Neurosurg Psychiatry 87, 295-301.

[29] Trezzi JP, Galozzi S, Jaeger C, Barkovits K, Brockmann K, Maetzler W, Berg D, Marcus K, Betsou F, Hiller K, Mollenhauer B (2017) Distinct metabolomic signature in cerebrospinal fluid in early parkinson's disease. Mov Disord 32, 1401-1408.

[30] Han W, Sapkota S, Camicioli R, Dixon RA, Li L (2017) Profiling novel metabolic biomarkers for Parkinson's disease using in-depth metabolomic analysis. Mov Disord 32, $1720-1728$.

[31] Willkommen D, Lucio M, Moritz F, Forcisi S, Kanawati B, Smirnov KS, Schroeter M, Sigaroudi A, Schmitt-Kopplin P, Michalke B (2018) Metabolomic investigations in cerebrospinal fluid of Parkinson's disease. PLoS One 13, $1-16$.

[32] Zhao H, Wang C, Zhao N, Li W, Yang Z, Liu X, Le W, Zhang X (2018) Potential biomarkers of Parkinson's disease revealed by plasma metabolic profiling. $J$ Chromatogr $B$ Anal Technol Biomed Life Sci 1081-1082, 101-108.

[33] Burté F, Houghton D, Lowes H, Pyle A, Nesbitt S, Yarnall A, Yu-Wai-Man P, Burn DJ, Santibanez-Koref M, Hudson G (2017) metabolic profiling of Parkinson's disease and mild cognitive impairment. Mov Disord 32, 927-932.

[34] Luan H, Liu LF, Tang Z, Zhang M, Chua KK, Song JX, Mok VCT, Li M, Cai Z (2015) Comprehensive urinary metabolomic profiling and identification of potential noninvasive marker for idiopathic Parkinson s disease. Sci Rep 5, 1-11.

[35] Luan H, Liu L-F, Meng N, Tang Z, Chua K-K, Chen LL, Song J-X, Mok VCT, Xie L-X, Li M, Cai Z (2015) LC-MS-based urinary metabolite signatures in idiopathic Parkinson's disease. J Proteome Res 14, 467-478.

[36] Flint HJ, Duncan SH, Scott KP, Louis P (2014) Links between diet, gut microbiota composition and gut metabolism. Proc Nutr Soc 760, 13-22. 
[37] Ahmed SS, Santosh W, Kumar S, Christlet H (2009) Metabolic profiling of Parkinson's disease: Evidence of biomarker from gene expression analysis and rapid neural network detection. J Biomed Sci 16, 63.

[38] Li L, Rose P, Moore PK (2011) Hydrogen Sulfide and Cell Signaling. Annu Rev Pharmacol Toxicol 51, 169-187.

[39] Cakmak YO (2015) Provotella-derived hydrogen sulfide, constipation, and neuroprotection in Parkinson's disease. Mov Disord 30, 1151-1151.

[40] Shen X, Carlström M, Borniquel S, Jädert C, Kevil CG, Lundberg JO (2013) Microbial regulation of host hydrogen sulfide bioavailability and metabolism. Free Radic Biol Med 60, 195-200.

[41] Kida K, Yamada M, Tokuda K, Marutani E, Kakinohana M, Kaneki M, Ichinose F (2010) Inhaled hydrogen sulfide prevents neurodegeneration and movement disorder in a mouse model of Parkinson's disease. Antioxid Redox Signal 15, 343-352.

[42] Hu LF, Lu M, Tiong CX, Dawe GS, Hu G, Bian JS (2010) Neuroprotective effects of hydrogen sulfide on Parkinson's disease rat models. Aging Cell 9, 135-146.

[43] Ostojic SM (2018) Inadequate production of $\mathrm{H} 2$ by gut microbiota and Parkinson disease. Trends Endocrinol Metab 29, 286-288.

[44] Fujita K, Seike T, Yutsudo N, Ohno M, Yamada H, Yamaguchi H, Sakumi K, Yamakawa Y, Kido MA, Takaki A, Katafuchi T, Tanaka Y, Nakabeppu Y, Noda M (2009) Hydrogen in drinking water reduces dopaminergic neuronal loss in the 1-methyl-4-phenyl-1,2,3,6-tetrahydropyridine mouse model of Parkinson's disease. PLoS One 4, 2-11.

[45] Fu Y, Ito M, Fujita Y, Ito M, Ichihara M, Masuda A, Suzuki Y, Maesawa S, Kajita Y, Hirayama M, Ohsawa I, Ohta S, Ohno K (2009) Molecular hydrogen is protective against 6hydroxydopamine-induced nigrostriatal degeneration in a rat model of Parkinson's disease. Neurosci Lett 453, 81-85.

[46] Suzuki A, Hamaguchi T, Ito M, Ohno K, Mori H, Watanabe T, Baba R, Kurokawa K, Asakawa S, Hirayama M, Takeda Y (2018) Quantification of hydrogen production by intestinal bacteria that are specifically dysregulated in Parkinson's disease. PLoS One 13, e0208313.

[47] Elsden SR, Hilton MG, Waller JM (1976) The end products of the metabolism of aromatic amino acids by clostridia. Arch Microbiol 107, 283-288.

[48] Lewitt PA, Li J, Lu M, Guo L, Auinger P (2017) Metabolomic biomarkers as strong correlates of Parkinson disease progression. Neurology 88, 862-869.

[49] Williams BB, Van Benschoten AH, Cimermancic P, Donia MS, Zimmermann M, Taketani M, Ishihara A, Kashyap PC, Fraser JS, Fischbach MA (2014) Discovery and characterization of gut microbiota decarboxylases that can produce the neurotransmitter tryptamine. Cell Host Microbe 16, 495503.

[50] Sridharan G V, Choi K, Klemashevich C, Wu C, Prabakaran D, Pan L Bin, Steinmeyer S, Mueller C, Yousofshahi M, Alaniz RC, Lee K, Jayaraman A (2014) Prediction and quantification of bioactive microbiota metabolites in the mouse gut. Nat Commun 5, 5492.

[51] Krishnan S, Ding Y, Saedi N, Choi M, Sridharan GV, Sherr DH, Yarmush ML, Alaniz RC, Jayaraman A, Lee K (2018) Gut microbiota-derived tryptophan metabolites modulate inflammatory response in hepatocytes and macrophages. Cell Rep 23, 1099-1111.

[52] Kim DC, Quang TH, Yoon CS, Ngan NTT, Lim S Il, Lee SY, Kim YC, Oh H (2016) Anti-neuroinflammatory activities of indole alkaloids from kanjang (Korean fermented soy source) in lipopolysaccharide-induced BV2 microglial cells. Food Chem 213, 69-75.

[53] Wikoff WR, Anfora AT, Liu J, Schultz PG, Lesley SA, Peters EC, Siuzdak G (2009) Metabolomics analysis reveals large effects of gut microflora on mammalian blood metabolites. Proc Natl Acad Sci U S A 106, 3698-3703.

[54] Saito Y, Sato T, Nomoto K, Tsuji H (2018) Identification of phenol- and p-cresol-producing intestinal bacteria by using media supplemented with tyrosine and its metabolites. FEMS Microbiol Ecol 94, 1-11.

[55] Trupp M, Jonsson P, Ohrfelt A, Zetterberg H, Obudulu O, Malm L, Wuolikainen A, Linder J, Moritz T, Blennow K, Antti H, Forsgren L (2014) Metabolite and peptide levels in plasma and CSF differentiating healthy controls from patients with newly diagnosed Parkinson's disease. $J$ Parkinsons Dis 4, 549-560.

[56] Kawakami K, Makino I, Kato I, Uchida K, Onoue M (2009) P-Cresol inhibits IL-12 production by murine macrophages stimulated with bacterial immunostimulant. Immunopharmacol Immunotoxicol 31, 304-309.

[57] Shiba T, Kawakami K, Sasaki T, Makino I, Kato I, Kobayashi T, Uchida K, Kaneko K (2014) Effects of intestinal bacteria-derived p-cresyl sulfate on Th1-type immune response in vivo and in vitro. Toxicol Appl Pharmacol 274, 191-199.

[58] Shiba T, Makino I, Kawakami K, Kato I, Kobayashi T, Kaneko K (2016) p-Cresyl sulfate suppresses lipopolysaccharide-induced anti-bacterial immune responses in murine macrophages in vitro. Toxicol Lett 245, 24-30.

[59] Neidle E, Hartnett C, Ornston LN, Bairoch A, Rekik M, Harayama S (1992) cis-diol dehydrogenases encoded by the TOL pWW0 plasmid xylL gene and the Acinetobacter calcoaceticus chromosomal benD gene are members of the short-chain alcohol dehydrogenase superfamily. Eur $J$ Biochem 204, 113-120.

[60] Rooks MG, Veiga P, Wardwell-Scott LH, Tickle T, Segata N, Michaud M, Gallini CA, Beal C, van Hylckama-Vlieg JET, Ballal SA, Morgan XC, Glickman JN, Gevers D, Huttenhower C, Garrett WS (2014) Gut microbiome composition and function in experimental colitis during active disease and treatment-induced remission. ISME J 8, 1403-1417.

[61] Olsen RH, Kukor JJ, Kaphammer B (1994) A novel toluene3-monooxygenase pathway cloned from Pseudomonas pickettii PKO1. J Bacteriol 176, 3749-3756.

[62] Bruins MR, Kapil S, Oehme FW (2000) Pseudomonas pickettii: A common soil and groundwater aerobic bacteria with pathogenic and biodegradation properties. Ecotoxicol Environ Saf 47, 105-111.

[63] Friedland RP (2015) Mechanisms of molecular mimicry involving the microbiota in neurodegeneration. JAlzheimers Dis 45, 349-362.

[64] Chen SG, Stribinskis V, Rane MJ, Demuth DR, Gozal E, Roberts AM, Jagadapillai R, Liu R, Choe K, Shivakumar B, Son F, Jin S, Kerber R, Adame A, Masliah E, Friedland RP (2016) Exposure to the functional bacterial amyloid protein curli enhances alpha-synuclein aggregation in aged Fischer 344 rats and Caenorhabditis elegans. Sci Rep 6, 1-10.

[65] Zogaj X, Bokranz W, Nimtz M, Römling U (2003) Production of cellulose and Curli fimbriae by members of the family. Infect Immun 71, 4151-4158.

[66] Choi JG, Kim N, Ju IG, Eo H, Lim SM, Jang SE, Kim DH, Oh MS (2018) Oral administration of Proteus mirabilis damages dopaminergic neurons and motor functions in mice. $S c i$ Rep 8, 1-13. 
[67] Marcobal A, de las Rivas B, Landete JM, Tabera L, Muñoz R (2012) Tyramine and Phenylethylamine Biosynthesis by Food Bacteria. Crit Rev Food Sci Nutr 52, 448-467.

[68] D’Andrea G, Pizzolato G, Gucciardi A, Stocchero M, Giordano G, Baraldi E, Leon A (2019) Different circulating trace amine profiles in de novo and treated Parkinson's disease patients. Sci Rep 9, 1-11.

[69] Perez M, Calles-Enríquez M, Nes I, Martin MC, Fernandez M, Ladero V, Alvarez MA (2015) Tyramine biosynthesis is transcriptionally induced at low $\mathrm{pH}$ and improves the fitness of Enterococcus faecalis in acidic environments. Appl Microbiol Biotechnol 99, 3547-3558.

[70] Torriani S, Gatto V, Sembeni S, Tofalo R, Suzzi G, Belletti N, Gardini F, Bover-Cid S (2008) Rapid detection and quantification of tyrosine decarboxylase gene (tdc) and its expression in gram-positive bacteria associated with fermented foods using PCR-based methods. J Food Prot 71, 93-101.

[71] van Kessel SP, Frye AK, El-Gendy AO, Castejon M, Keshavarzian A, van Dijk G, El Aidy S (2019) Gut bacterial tyrosine decarboxylases restrict levels of levodopa in the treatment of Parkinson's disease. Nat Commun 10, 310.

[72] Maini Rekdal V, Bess EN, Bisanz JE, Turnbaugh PJ, Balskus EP (2019) Discovery and inhibition of an interspecies gut bacterial pathway for Levodopa metabolism. Science 364, eaau6323.

[73] Nagai Y, Ueno S, Saeki Y, Soga F, Hirano M, Yanagihara $\mathrm{T}$ (1996) Decrease of the D3 dopamine receptor mRNA expression in lymphocytes from patients with Parkinson's disease. Neurology 46, 791-795.

[74] Rajda C, Dibó G, V ecsei L, Bergquist J (2005) Increased dopamine content in lymphocytes from high-dose L-Dopa-treated Parkinson's disease patients. Neuroimmunomodulation 12, 81-84.

[75] Caronti B, Tanda G, Colosimo C, Ruggieri S, Calderaro C, Palladini G, Pontieri FE, Di Chiara G (1999) Reduced dopamine in peripheral blood lymphocytes in Parkinson's disease. Neuroreport 10, 2907-2910.

[76] Kustrimovic N, Rasini E, Legnaro M, Bombelli R, Aleksic I, Blandini F, Comi C, Mauri M, Minafra B, Riboldazzi G, Sanchez-Guajardo V, Marino F, Cosentino M (2016) Dopaminergic receptors on CD4+ T naive and memory lymphocytes correlate with motor impairment in patients with Parkinson's disease. Sci Rep 6, 1-17.

[77] Pinoli M, Marino F, Cosentino M (2017) Dopaminergic regulation of innate immunity: A review. J Neuroimmune Pharmacol 12, 602-623.

[78] Sarkar C, Basu B, Chakroborty D, Dasgupta PS, Basu S (2010) The immunoregulatory role of dopamine: An update. Brain Behav Immun 24, 525-528.

[79] Alves G, Wentzel-Larsen T, Aarsland D, Larsen JP (2006) Progression of motor impairment and disability in Parkinson disease. Neurology 65, 1436-1441.

[80] Kustrimovic N, Comi C, Magistrelli L, Rasini E, Legnaro M, Bombelli R, Aleksic I, Blandini F, Minafra B, Riboldazzi G, Sturchio A, Mauri M, Bono G, Marino F, Cosentino M (2018) Parkinson's disease patients have a complex phenotypic and functional Th1 bias: Cross-sectional studies of CD4+ Th1/Th2/T17 and Treg in drug-nä̈ve and drugtreated patients. J Neuroinflammation 15, 1-17.

[81] Kipnis J (2004) Dopamine, through the extracellular signalregulated kinase pathway, downregulates CD4+ CD25+ regulatory T-cell activity: Implications for neurodegeneration. J Neurosci 24, 6133-6143.
[82] Gonzalez H, Contreras F, Prado C, Elgueta D, Franz D, Bernales S, Pacheco R (2013) Dopamine receptor D3 expressed on CD4+ T cells favors neurodegeneration of dopaminergic neurons during Parkinson's disease. $J$ Immunol 190, 5048-5056.

[83] Zhu H, Lemos H, Bhatt B, Islam BN, Singh A, Gurav A, Huang L, Browning DD, Mellor A, Fulzele S, Singh N (2017) Carbidopa, a drug in use for management of Parkinson disease inhibits $\mathrm{T}$ cell activation and autoimmunity. PLoS One 12, 1-15.

[84] Ogura J, Miyauchi S, Shimono K, Yang S, Gonchigar S, Ganapathy V, Bhutia YD (2017) Carbidopa is an activator of aryl hydrocarbon receptor with potential for cancer therapy. Biochem J 474, 3391-3402.

[85] Gutiérrez-Vázquez C, Quintana FJ (2018) Regulation of the immune response by the aryl hydrocarbon receptor. Іттиnity 48, 19-33.

[86] Kouassi E, Yue Sheng Li, Boukhris W, Millet I, Revillard JP (1988) Opposite effects of the catecholamines dopamine and norepinephrine on murine polyclonal B-cell activation. Immunopharmacology 16, 125-137.

[87] Macpherson AJ, Köller Y, McCoy KD (2015) The bilateral responsiveness between intestinal microbes and $\operatorname{IgA}$. Trends Immunol 36, 460-470.

[88] Houser MC, Chang J, Factor SA, Molho ES, Zabetian CP, Hill-Burns EM, Payami H, Hertzberg VS, Tansey MG (2018) Stool immune profiles evince gastrointestinal inflammation in Parkinson's disease. Mov Disord. 33, 793-804.

[89] Pryde SE, Duncan SH, Hold GL, Stewart CS, Flint HJ (2002) The microbiology of butyrate formation in the human colon. FEMS Microbiol Lett 217, 133-139.

[90] Lewitt PA, Li J, Lu M, Beach TG, Adler CH, Guo L (2013) 3-hydroxykynurenine and other Parkinson's disease biomarkers discovered by metabolomic analysis. Mov Disord 28, 1653-1660.

[91] Öhman A, Forsgren L (2015) NMR metabonomics of cerebrospinal fluid distinguishes between Parkinson's disease and controls. Neurosci Lett 594, 36-39.

[92] Wuolikainen A, Jonsson P, Ahnlund M, Antti H, Marklund SL, Moritz T, Forsgren L, Andersen PM, Trupp M (2016) Multi-platform mass spectrometry analysis of the CSF and plasma metabolomes of rigorously matched amyotrophic lateral sclerosis, Parkinson's disease and control subjects. Mol Biosyst 12, 1287-1298.

[93] Havelund JF, Andersen AD, Binzer M, Blaabjerg M, Heegaard NHH, Stenager E, Faergeman NJ, Gramsbergen JB (2017) Changes in kynurenine pathway metabolism in Parkinson patients with L-DOPA-induced dyskinesia. $J$ Neurochem 142, 756-766.

[94] Johansen KK, Wang L, Aasly JO, White LR, Matson WR, Henchcliffe C, Beal MF, Bogdanov M (2009) Metabolomic profiling in LRRK2-related Parkinson's disease. PLoS One 4, 1-9.

[95] Roede JR, Uppal K, Park Y, Lee K, Tran V, Walker D, Strobel FH, Rhodes SL, Ritz B, Jones DP (2013) Serum metabolomics of slow vs. rapid motor progression Parkinson's disease: A pilot study. PLoS One 8, 1-11. 